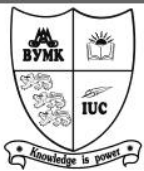

European Journal of Tourism Research

http://ejtr.vumk.eu

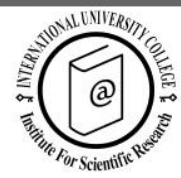

\title{
France, R. L. (2011). Veniceland Atlantis the Bleak Future of the World's Favourite City, Libri Publishing, 145 pages, ISBN 978-1-907471-31-5.
}

\author{
Reviewed by Miroslava Dimitrova ${ }^{1}$
}

Received: 20.02.2012

${ }^{1}$ International University College, Dobrich, Bulgaria, e-mail: miroslava.dimitrova@vumk.eu

(c) 2012 International University College. All rights reserved

Citation: France, R. L. (2011). Veniceland Atlantis the Bleak Future of the World's Favourite City, Libri Publishing, 145 pages, ISBN 978-1-907471-31-5. Reviewed by Miroslava Dimitrova, European Journal of Tourism Research 5(1), pp. 89-91

This book tells the story of one of the most beloved cities in the world. Often referred to as the Queen of the Adriatic Sea, Venice has enthralled many generations with her majestic beauty. Unfortunately its existence is threatened by a number of perils and though it had bravely stood against the sea waters for centuries, it is doubtful whether the city is going to survive the flood of tourists that overcrowds its streets in the last few decades. This book is dedicated to Venice, but not the Venice we know from the tourist brochure and Hollywood movies, but with its bitter problems and its fears for the future. This book aims to tell "the truth about Venice" and every reader will be surprised to find that beneath the gloss and the aura of romance, it is a place torn with contradictions and problems unsolved for years.

The book is divided into four chapters which logically follow one after another. The first one is called "Aqua Alta" and addresses the various threats and perils that challenge Venice's existence. The natural processes related to ever rising ocean level are the main reason for the so-called "sinking feeling". Lack of proper waste disposal system and modern BOOK REVIEW infrastructure is another big issue which turns Venice into the "most beautiful toilet in the world". For centuries the lagoon of Venice had been a battlefield of people versus wetlands. Nowadays the development of new territories is weighted by the possible negative impacts on the precarious eco-balance and wild life preservation. In fact human activity in the region is the main culprit for the sinking outcome. Because of too much construction in the region the natural wetlands ability to absorb the tides has diminished thus exacerbating the problem. A series of photos (called "Scab of Venice") following Chapter 1 illustrates the narration. Pictures of flooded streets, ruined houses and scattered rubbish give a good visualization on the gravity of the situation.

Chapter 2 is called "Protecting and Rebuilding Venice" and as the title implies gives account on various measures that had been considered for prevention and restoration of Venice. The most notable project is "Modulo Sperimentale Electtromeccanico" or "MOSE". The latter acronym is a playful reference to a biblical character and his proverbial act of separating the water of the Red Sea. Likewise the MOSE project is intended to separate the lagoon of 
Venice from the Adriatic Sea by a system of mobile flood gates. The proposition came out in the 1970s, but since then it was followed by long debates on whether and how it should be implemented thus leading to futile procrastination. The controversies about MOSE are various. They are based on ecological (whether the project won't prove detrimental for the wildlife in the lagoon) and economical concerns (whether the enormous financial endeavour will be justified). The biggest problem however is that due to populist ambitions, the Italian government postpones the solution of the problem for decades now, avoiding the responsibility of taking definite decision about Venice's future. The photo session that follows the second chapter gives more optimistic view about the engineering work and regeneration of the landscape that has been carried out in Venice and the surrounding areas.

Chapter 3 is called "Veniceland, Invasion of the City Snatchers" and is probably one of the saddest parts of the book. It is not the Nature that threatens most the legendary city, but another recent and monstrous phenomenon this of the mass tourism. People arriving by cruises, trains and buses are invading the city and outnumbering the local population. Most of the workers employed in the service industry are commuting each day from their homes to Venice, thus contributing to the crowd and pollution. Mass tourists rarely have knowledge and willingness to interact with the cultural attractions that Venice offers. Surprisingly some of them do not visit any museums or cathedral and do not spend much during their stay. Majority of tourist (e.g., those arriving with cruises) don't use accommodation either so they don't contribute financially to the city's welfare. Though tourism may seem as a big and profitable business the conclusion is that local people experience mostly the drawbacks of a mass tourism including overcrowded streets, pollution, waste disposal issues and other inconveniences (such as lack of basic goods and services while everything is intended to procure for visitors and not for residents). As a result the local population diminishes every year. If this trend continues
Venice would soon become an artificial destination, a beautiful scenery staging performances for tourists. The idea of "Veniceland" (allusion with Disneyland) is not as absurd as it may seem on first glance and it was a subject of several academic and social debates. Developing Venice as an enormous theme park would at least suggest paying an entrance fee, better management and more benefits for the city itself. Though commodification of Venice may sound a bit too extreme, some measurements should be taken so that locals are not any longer ignored in favour of the tourists. Limit access to Venice could be a possible solution but it poses more problems than gives solutions to existing ones. Again the photos at the end of the chapter illustrate the above said: big ships disembarking thousands of visitors, crowded streets and squares, kitschy souvenirs (such as carnival masks manufactured in China) etc.

Chapter 4 or "Petulance, Prejudice and Politics in Saving a Dying City" attempts to answer the question "If so many problems exist and everybody knows it, why nobody cares and so little is done?". The Chapter is an overt criticism of the Italian government and Venetian local authorities who seem to be too scared to face the problems. A good example is the continued indecisiveness about MOSE project (previously discussed) or any other project that may have more tangible effect on Venice flood problem. Interesting comparisons with other similar cases are given. The photo essay following the chapter depicts the controversies by showing posters with projects information as well as relevant documentation

Next section of the book is the Conclusion in which the author recapitulates his observation of the perilous situation in Venice, the possible solutions and challenges before their implementation. The last section is an interesting self-reflective interview in which the author shares his own feelings on the matters that are discussed in the book in a most neutral and objective way. The author presents its own pessimistic and optimistic prognosis about Venice's future. No scenario is impossible and 
with a proper management the bleak future may be brightened.

Though Venice's problems had been a topic of many academic debates, this book (according to the author) is the first attempt to compile them all: natural, ecological, social and economic issues that challenge Venice existence and its future development. Style of writing is praiseworthy combining both academic austerity and literature exquisiteness spiced with witty humor and playful allusions. The abundance of illustrations (there is a webbased colour photos with link provided) and well-thought structure (photos succeed text after each chapter) contribute to the vividness of the story and involve the reader further into the matter. Though this book is exclusively about Venice it can provoke discussions about social and ecological impacts of tourism in any destination. Venice is a good case study of the complexity of the issues and fragility of the balance in sustainable development of a tourist destination. The future of Venice seems bleak as the book title suggests but hope still exists that with proper management Venice won't be turned into the new Atlantis - engulfed by the sea waters or Veniceland - a staged playground for mass tourism. 